\title{
Capacity Building of Associate Professors for Improving Lecturers' Performance: A Case Study in a Leading University in Indonesia
}

\author{
Andita Fitriana \\ Educational Administration \\ Universitas Pendidikan Indonesia \\ Bandung, Indonesia \\ nditafitriana@gmail.com \\ Diding Nurdin \\ Educational Administration \\ Universitas Pendidikan Indonesia \\ Bandung, Indonesia \\ didingnurdin@upi.edu
}

\author{
Djam'an Satori \\ Educational Administration \\ Universitas Pendidikan Indonesia \\ Bandung, Indonesia \\ djamansatori@yahoo.com
}

\begin{abstract}
Nowadays, the duty of a lecturer is not merely teaching but also becoming a professional teacher as well as a scientist who is responsible for transforming, developing and disseminating knowledge, technology and arts through teaching, research, and community service. Associate professors in a university are professor candidates who should build their capacity to help this nation reach the ultimate objectives of education. In reality, quite many associate professors delay their promotions to full professors as they have got an abundance of business as well as limited time to conduct outstanding studies. Hence, this study was conducted to disclose the development of associate professors' capacity building at Faculty of Engineering, Universitas Gadjah Mada (UGM), as one of the best colleges in Indonesia. This study applied qualitative approach with purposive and snowball sampling techniques. The findings showed that: there was no specific capacity building program for associate professors at Faculty of Engineering UGM. However, there were some capacity building programs held for all lecturers at Faculty of Engineering UGM such as: promotion socialization, research grants workshops, reference management software workshops, workshops on international journal writing, and international publication preparation programs. The success indicator of the capacity building was when the number of promotion from associate professors to full professors has increased up to $10 \%$ among the total number of 107 associate professors at this faculty. This study revealed that limited number of studies and international publications became the most problematic causes of this promotion delay, as these two aspects were the basic requirements. To overcome this problem, UGM conducted International Publication Preparation Program (PPI), yet this program has not been specifically addressed to the associate professors. Besides, UGM had also equipped the lecturers with various facilities and supporting programs to encourage their capacity building.
\end{abstract}

Keywords: capacity building, lecturers' performance, and higher education

\section{INTRODUCTION}

Manufacturing industries play an important role in the economic development of this country, especially after the establishment of ASEAN Economic Community 2015. The government needs to complement the development of manufacturing industries with sufficient infrastructure for achieving the optimum development. The provision of skilful and educated employees becomes one of the most important development requirements. This is higher education institutions' responsibility to produce well-trained workers based on the current demands of job market and well-trained workers who are able to compete not only locally but also globally. Higher education institutions (HEI) should be able to help these students to be professionals in terms of knowledge, technology, management, and leadership because these competencies are necessary in this global era.

Since human resources are very crucial in global competition, they should be managed well. [1] "Human resource management is defined as a strategic and coherent approach to the management of an organization's most valued assets - the people working there who individually and collectively contribute to the achievement of its objectives". The most valuable feature of an organization is 'people' because people will work either individually or collectively to achieve the objectives of the organization. This definition is related to the term 'performance', which is defined as one's ability to accomplish his/her tasks and responsibilities. One way to measure one's performance is to observe his/her ability and motivation. A person's performance is directly proportional to the ability and motivation. In university level, the ability to create competitive graduates also depends on the quality of the lecturers' performance. Lecturers have a central role as educators, thus they should keep optimizing their 
performance and ability to reach the objectives of their institution. One of these objectives is creating competent graduates.

To become a qualified university or even a world-class university, there are a lot of works to be accomplished. It is argued that a world-class university owns three indicators as follows: (1) excellence in education of their students; (2) research, development and dissemination of knowledge; and (3) activities contributing to the cultural, scientific, and civic life of society [2]. Generally, to be considered a qualified institution, every university in Indonesia has the responsibility to give high quality learning, conduct beneficial studies, and do community service. So, lecturers' performance as the key factor of a higher education institution's quality needs to be developed. Each institution also has its own problem related to the effort to build lecturers' capacity building, particularly the problem of promotion from associate professors to full professors. The official statistics of Faculty of Engineering UGM disclosed that this faculty only had a few number of professors, only about $13 \%$ among the whole number of lecturers at this faculty. Based on the findings of this study at the site, the researchers discovered several problems related to the promotion delay from associate professor to full professor such as the requirement to have indexed research journals, the high precision of the proposed promotion as the assessors will evaluate thoroughly, the minimum decencies that should be fulfilled in each academic position of a lecturer, the abundance of activities that never let associate professors to entirely achieve quality in the three pillars of higher education (teaching, research, and community service), and the unstructured documentations of each academic activities of the lecturers. The researchers thought that it was worth trying to disclose the programs for capacity building, the success indicators, the problems and the solutions, as well as the facilities offered by the institution to support the capacity building of the lecturers, particularly the associate professors at Faculty of Engineering Unversitas Gadjah Mada.

\section{RESEARCH METHOD}

The design of this study was descriptive research with qualitative approach. Qualitative approach was selected since this research aimed at holistically understanding the phenomenon experienced by the research subjects. The phenomenon was then described naturally in words in a specific context using various scientific methods. The subjects were selected using purposive and snowball sampling techniques. The data collection techniques were interviews, document analysis, and data triangulation between the interviews and the document analysis. The researchers were not able to conduct observation as they had limited access and chance to watch each programs hold by Faculty of Engineering Universitas Gadjah Mada. The data analysis techniques covered data organization, data reduction, data display, and conclusion drawing/verification.

\section{RESEARCH FINDINGS AND DISCUSSIONS}

\section{Findings}

1. The Types of Capacity Building Programs for the Associate Professors

a. There was no specific capacity building programs addressed to promote associate professors to full professors

b. The capacity building programs at Faculty of Engineering UGM were generally addressed to all lecturers, without distinguishing the academic positions of the lecturers. These programs were: (1) promotion socialization, in which the materials were taken from Credit Score and Promotion Guideline and in which there was a sharing session for the lecturers to exchange information related to international publication; (2) research grant workshops for the lecturers, in which it enlightened the them related to the tips to win research grants; (3) reference management software workshops, where the lecturers were trained to get accesses to some databases which provide online journals and to deal with reference citations; (4) workshops on international journal writing, which covered the tips and methods so that their writings could be accepted as well as published in international publications; (5) International Publication Preparation Program (PPI) as well as many other related activities based on the needs of the lecturers such as PPI program socialization, proposal submission and selection, reference utilization training, assistance for the submitted proposals, proofreading, translation, and symposium for monitoring the smoothness of the journal submission process.

c. Each capacity building program conducted by Faculty of Engineering UGM referred to the government regulations of lecturers' performance development such as the regulation of the Minister of State Apparatus Utilization and Bureaucratic Reform of the Republic of Indonesia (Minister of PAN-Wed) No 17/2013 as well as the operational guideline for evaluating lecturers' promotion credit scores. This government regulation was translated into various capacity building programs for improving the lecturers' performance.

d. The lecturers' capacity building was based on the official statistics of Faculty of Engineering UGM. The statistics were then analysed, adjusted with the expected development, and translated into various capacity building programs.

e. The stages of the capacity building programs were: (1) Preparation stage: identifying the programs that needed to be developed, referring to the government regulations; (2) Analysis stage: analysing various activities to be held based on the statistics; (3) Planning stage: planning the programs, including the time, venue, materials, and 
so on; (4) Implementation stage: implementing the planned programs; and (5) Evaluation stage: monitoring the possible improvements based on the statistics after the implementation of the programs. In this stage, the person in charge or the leader of the faculty could directly invite the problematic lecturers to discuss their problems as well as to find the solution to their problems.

f. Faculty of Engineering UGM had not formulated a specific penalty for lecturers who had no publication, had lack of attendance, and had not proposed their promotion. However, this faculty gave rewards to the lecturers in many forms such as they deserved performance allowance increment when they could successfully publish their writings in indexed journals and they also deserved 10 to 15 billion rupiahs when their papers were published in international indexed journals such as Scopus, Thomson, Web of Science, and Microsoft Academic.

g. Faculty of Engineering UGM used InEMS (Internal Emailing System) for their digital-based documentation system. HRIS (Human Resource Information System) was an information system, which was related to human resources, particularly about personnel administration, personal data, personnel transfers, employees, salaries, reports, attendance, and other related information. In HRIS application, there was SIMASTER employee portal, which should be fulfilled as it was related to Employee Performance Goals (Sasaran Kinerja Pegawai). Prisma UGM was an application designed for archiving lecturers' research and community service data. Magister JTETI, a research documentation system in Electrical Engineering and Information Technology Department Faculty of Engineering UGM, enabled the lecturers to check and to monitor their credit scores because this system could accumulate the total credit scores from the research activities. Promotion Monitoring was a database, which was specifically designed to monitor every promotion of the lecturers and staffs at Faculty of Engineering UGM.

2. The Success Indicators of Associate Professors' Capacity Building Programs

Faculty of Engineering UGM aimed at increasing the number of its professors up to $10 \%$. This calculation was determined based on the total number of associate professors in this faculty. Nevertheless, they found it difficult to reach this target of promotion due to several reasons that had been discussed previously. The success indicator of the promotion socialization program was the lecturers' capability to complete the related documents for their promotion as well as their ability to meet the promotion requirements. The success indicator of the workshop on reference management software was when the lecturers were able to utilized various application for the purpose of citation, such as Mendeley application for finding the source of a reference and its citation. The success indicator of the workshop on international journal writing was then the lecturers were finally able to write standardized papers and able to publish their papers in international indexed journals. The success indicator of research grant workshop was when the lecturers could win research grants from the department, the faculty, the university, or from Indonesian Directorate General of Higher Education (DIKTI). The success indicator of the International Publication Preparation Program (PPI) was when the selected papers of the lecturers could be published in an indexed publication.

3. The Problems and Solution of Associate Professors' Capacity Building Programs

The most problematic issue related to associate professors' promotion to full professors was the change of the promotion requirements announced by the government. The requirements were getting harder to be realized, especially the obligation for these lecturers to have international publications. To conquer this serious problem, the faculty conducted a variety of programs and events to encourage the lecturers to write more, such as workshops on international journal writing, workshops on reference management software utilization, and International Publication Preparation Program (PPI).

4. The Facilities Offered by Faculty of Engineering UGM for Associate Professors' Capacity Building Facilities are provided by an institution to support the performance development of its employees. Regarding this notion, Faculty of Engineering UGM also provided numerous facilities to enable the lecturers' work at ease. The facilities could be used to support their knowledge development and other professional developments. These facilities covered: browsing management tool training, proofreading service, conference and publication funds for each lecturer annually both in Indonesia and overseas, the rights to get research grants, the authority for all department within Faculty of Engineering UGM to formulate their own policy based on their own factual conditions, the freedom to access journal subscriptions, the assistance to get the necessary references when they could not be found in the subscribed journals, specific staff(s) to help the lecturers succeed their promotion, facilities from Microsoft innovation centre, and free internet access for UGM staffs to subscribe to speedy internet service at home by using UGM bandwidth. 


\section{Discussions}

Lecturers' capacity building programs are conducted to increase lecturers' performance. According to [3] human resources development is a learning process for the employees to work more systematically to improve their competency and responsibility at this present period and to prepare themselves for the challenges and responsibilities in the future. In line with this outlook, capacity building becomes an effort to prepare oneself for the future jobs. Lecturers as the forefront of HEIs also need to build their capacity in order to gain the objectives of the national education, which is not only educating the pupils but also making them ready to compete globally. Lecturers' capacity building should be focused on their ability to transform themselves to answer the future challenges according to the required demands [4] states as follows:

Development is concerned that a person's ability and potential grows through the provision of learning experiences or through self-directed (self-managed) learning. It is an unfolding process, which enables people to progress from a present state of understanding and capability to a future in which higher-level skills, knowledge and competencies are required.

Armstrong's point of view should be emphasized on the aspect of '...capability to a future in which higherlevel skills, knowledge and competencies are required'. The first aspect implies that lecturers' capacity in the future should be higher, which in other words means that they should be able to compete globally. This notion is stated in the Operational Guideline for Evaluating Lecturers' Promotion Credit Scores [5] that lecturers as one of the most vital components in higher education system play a significant role in the success of HEIs. Studies in Bosnia and Herzegovina found that there was a major impact and change towards employees' performance after some trainings and capacity building programs [6]. Such programs enable employees to develop their skills and ideas for the development of their career in the near future. Lecturers are expected to be able to adjust their capacity to chase the development of science, technology, and arts within Asian countries in particular and in global scale in general. It also means that lecturers should develop their capacity in order to fruitfully compete with other lecturers from other universities in the world and to produce competitive graduates.
Furthermore, it is pointed out that the second aspect is the required competencies. If the goal of education is to keep the pace with other countries in terms of knowledge and science development, Indonesia should also possess an equal development in its education achievements. Thus, Indonesian HEIs should attempt to be world-class universities. As it is stated previously, a worldclass university has the following indicators: (1) excellence in education of their students; (2) research, development and dissemination of knowledge; and (3) activities contributing to the cultural, scientific, and civic life of society. It means a higher education institution will be considered a world-class university when it excels in providing the best education for its students, in conducting research and disseminating knowledge, and in the contribution to the development of cultures, science, and society. These indicators are similar to lecturers' professional duties (three pillars of higher education), which require them to give the best education service, to conduct useful studies, and to do community services.

As scientists, lecturers also have a duty to conduct outstanding and useful studies which contribute to the development of knowledge. The operational guideline for evaluating lecturers' promotion credit scores becomes one of the regulations, which points out the necessity for lecturers to build their capacity as professional educators. Through this parameter, lecturers are recommended to develop the quality of their studies as well as to increase the number of their publications. The studies and publications of all scientists in the world are fused in Scimago JR, a foundation that ranks all journals from all around the world, which are indexed by Scopus international database.

Indonesia is ranked 57 of 236 countries, which the journals are indexed globally. Compared to the positions of developed countries, Indonesia's position is left behind. Hence, all lecturers are encouraged to publish their writings in international indexed journals. This responsibility is stated in the operational guideline for evaluating lecturers' promotion credit scores. This policy is also stated in the regulation of the Minister of State Apparatus Utilization and Bureaucratic Reform of the Republic of Indonesia [7] No $17 / 2013$, in which there are minimum percentages of some elements that must be met by lecturers to apply for a promotions as well as the promotion credit scores as follows:

Table 1: The Percentage of Each Element for Lecturer Promotion

Table 1: The Percentage of Each Element for Lecturer Promotion
\begin{tabular}{|c|c|c|c|c|c|}
\hline \multirow{2}{*}{ Position } & $\begin{array}{c}\text { Academic } \\
\text { Qualification }\end{array}$ & $\begin{array}{c}\text { Education } \\
\text { and } \\
\text { Teaching }\end{array}$ & Research & $\begin{array}{c}\text { Community } \\
\text { Service }\end{array}$ & $\begin{array}{c}\text { Supporting } \\
\text { Aspect }\end{array}$ \\
\hline $\begin{array}{c}\text { Associate } \\
\text { Lecturer }\end{array}$ & Master & $\geq 55 \%$ & $\geq 25 \%$ & $\leq 10 \%$ & $\leq 10 \%$ \\
\hline Lecturer & Master & $\geq 45 \%$ & $\geq 35 \%$ & $\leq 10 \%$ & $\leq 10 \%$ \\
\hline $\begin{array}{c}\text { Associate } \\
\text { Professor }\end{array}$ & Doctor & $\geq 40 \%$ & $\geq 40 \%$ & $\leq 10 \%$ & $\leq 10 \%$ \\
\hline Professor & Doctor & $\geq 35 \%$ & $\geq 45 \%$ & $\leq 10 \%$ & $\leq 10 \%$ \\
\hline
\end{tabular}


Table 2: The Total Number of Cumulative Promotion Credit Scores

\begin{tabular}{|c|c|c|c|c|c|c|c|c|}
\hline \multirow{3}{*}{ Description } & \multirow{3}{*}{ Percentage } & \multicolumn{7}{|c|}{$\begin{array}{l}\text { Academic Rank/Category and Credit Scores of Lecturers' } \\
\text { Academic Position (Doctor) }\end{array}$} \\
\hline & & \multicolumn{2}{|c|}{ Lecturer } & \multicolumn{3}{|c|}{ Associate Professor } & \multicolumn{2}{|c|}{ Professor } \\
\hline & & $\mathrm{III} / \mathrm{c}$ & III/d & IV/a & $\mathrm{IV} / \mathrm{b}$ & $\mathrm{IV} / \mathrm{c}$ & IV/d & IV/e \\
\hline $\begin{array}{l}\text { MAIN ASPECTS } \\
\text { A. Academic Qualification }\end{array}$ & & 200 & 200 & 200 & 200 & 200 & 200 & 200 \\
\hline $\begin{array}{l}\text { B. Education and Teaching } \\
\text { C. Research } \\
\text { D. Community Service } \\
\text { E. Professional Development }\end{array}$ & $<90 \%$ & - & 90 & 180 & 315 & 450 & 625 & 765 \\
\hline $\begin{array}{c}\text { SUPPORTING ASPECT } \\
\text { (Lecturers' supporting academic activity) }\end{array}$ & $<10 \%$ & - & 10 & 20 & 35 & 50 & 75 & 85 \\
\hline $\begin{array}{c}\text { Total } \\
\end{array}$ & & 200 & 300 & 400 & 550 & 700 & 850 & 1050 \\
\hline
\end{tabular}

The evaluation of the credit scores of each aspect in a promotion refers to the operational guideline for evaluating lecturers' promotion credit scores from associate professor to full professor (2014). Previously, the operational guideline for evaluating lecturers' promotion credit scores from associate professor to full professor (2009) was used. In the previous regulation, the percentage of each aspect (education, research and community service) was not specifically classified. It merely informed the minimum and the maximum credit scores which needs to be met by the lecturers. In the latest regulation 2014, the percentage of each aspect in each academic position promotion is clearly divided. Thus, lecturers should carefully check their cumulative credit scores if they want to apply for promotion. Despite the clear information of the credit scores, this new regulation makes many lecturers delay their promotion as they realize the incompleteness in their credit scores in some aspects. The most fundamental problem in this case is the fulfilment of the research aspect in the form of international indexed journals or publications.

Considering that nowadays the requirements for lecturer promotion are getting harder and harder, Faculty of Engineering Universitas Gadjah Mada holds an abundance of capacity building programs for the lecturers. However, the faculty needs to conduct needs analysis to identify the necessary capacity building programs so that the programs will be truly beneficial for the lecturers. Needs analysis is crucial as it provides data and information related to the lecturers' perceptions, behaviours, and skills. [8] states that needs analysis as the initial stage of a program development is necessary for giving a clear picture of the needs of the participants of the program, just like a diagnostic stage. This diagnostic stage helps a researcher to identify possible problems in an organization's and its employees' performance, which further is useful to determine the significance of the training or the program development which is conducted. The role of a needs analysis which is proposed by Mathis \& Jackson is nearly the same with that propose by Gomes [9], in which the purpose of a needs analysis is to collect relevant information as much as possible to decide whether a program is necessary to be conducted or not. A study conducted by Khan [10]) found that the roles of training and development program become a crucial issue in an organization. The stages of the training were began with an identification of the problems (or socalled needs analysis) that occurred in the training and development program; and were continued with the design of the training and development program; the programs were then implemented; and finally an evaluation was conducted as the ultimate stage of the training and development programs. The key factor to measure the effectiveness of the training and development programs was actually the support from the management towards the sustainable use of the results of the training and development programs in the workplace. Additionally, the sources of the needs analysis of a training and development program were organizational analysis, job description analysis, and individual analysis.

Once the needs analysis stage was accomplished, a program developer needs to decide the necessary programs or activities to overcome the existing problems. Robbins [11] argues, "Human resource management goals are accomplished through the functions of staffing, training and development, motivation and maintenance. External factors influencing the process are labour relation, management practise, government legislation, and globalization". A program developer should also find the possible solution to the problems related to the existing policy. For instance, in the case of this study, the associate professors at Faculty of Engineering UGM had inadequate time to conduct outstanding studies as well as to publish journals since they were busy with an abundance of activities, whereas the government kept forcing them to increase the quantity of their research and publications. To conquer this dilemma, the faculty held the International Publication Preparation Program (PPI) where the lecturers could work collaboratively with the students to write papers for the purpose of publications. The continuation of the International Publication Preparation Program (PPI) and its supporting activities could excel the lecturers' ability to write more journals and publish them in international indexed journals. With such training, lecturers can significantly feel the advantages such as a study conducted by Fakhra Aziz [12], which revealed that the training programs for teachers in Pakistan gave positive impact to the teachers' capacity building. The trained teachers became 
more competent in many aspects rather than those who did not get the training. Overall, training or professional development programs aims at improving the capacity of educators in order to gain the expected competencies.

\section{CONCLUSION}

Faculty of Engineering Universitas Gadjah Mada had provided a number of programs to support the lecturers' capacity building. These programs particularly aimed at improving the quantity of the international publications of the lecturers. However, the faculty had not conducted specific programs for the associate professors' capacity building. The International Publication Preparation Program (PPI) should be distinctively addressed to these associate professors. Besides, this program should also offer more proportion to the associate professors so that they could be more productive in writing papers to be published in indexed research journals. In addition to these programs, Faculty of Engineering UGM also provided the lecturers with various facilities for their capacity building. The facilities given by the faculty and university were plentiful and were more than enough so they should not have any more excuse not to increase their international publications.

\section{ACKNOWLEDGEMENT}

The researchers would like to express their sincere gratitude to Universitas Gadjah Mada for the precious opportunity to conduct this study at Faculty of Engineering UGM.

\section{REFERENCES}

[1] M. Amstrong, A Handbook of Human Resource Management Practice 10th ed., London: Cambridge University Press, 2006.

[2] D. W. J. \&. D. O. Henry M. Levin, "What is World ClassUniversity?," Hawai, 2006.

[3] A. Ruky, Sumber Daya Manusia Berkualitas, Jakarta: PT Gramedia Pustaka Utama, 2006.

[4] M. Amstrong, Amstrong's Essentential Human Resource Management Practice: A Guide To People Management, London: Replika Press Pvt Ltd, 2010.

[5] D. J. P. T. K. P. d. Kebudayaan, "Pedoman Operasional Penilaian Angka Kredit Kenaikan Pangkat/Jabatan Akademik Dosen," Direktorat Jenderal Pendidikan Tinggi Kementrian Pendidikan dan Kebudayaan, Jakarta, 2014.

[6] S. \&. C. E. Bayraktaroglu, "Impact of Training and Development on Employee Performance in Bosnia and Herzegovnia," European Researcher, vol. 89, pp. 2125 - 2133, 2014.

[7] K. P. A. Negara, Jabatan Fungsional Dosen dan Angka Kreditnya, Jakarta: Kementrian Pendayagunaan Aparatur Negara, 2013.

[8] R. M. J. \&. J. H, Human Resources Development, Jakarta: Prestasi Pustaka, 2006.

[9] F. C. Gomes, Manajemen Sumber Daya Manusia, Yogyakarta: Penerbit Andi, 2003.

[10] J. R. \&. S. Khan, "Training and Development Function in Omani Public Sector Organizations: A Critical Evaluation," Journal of Applied Bussines and Economics, vol. 14, pp. 37 - 52, 2013.

[11] D. A. D. \&. S. P. Robbins, Fundamentals of Human Resources Management 10 Edition, USA: John Willey \& Sons, Inc, 2010.

[12] F. A. e. al, "Impact of Training on Teachers Competencies at Higher Education Level in Pakistan," Research World, no. 5.1, pp. 121 $128,2014$. 